\title{
The Effects of Farmers-Herders Conflict on Farming Households in Southern Taraba State, Nigeria
}

\section{${ }^{*}$ Corresponding Author} \\ Rukwe DT \\ Article History \\ Received: 22.10.2019 \\ Accepted: 31.10 .2019 \\ Published: 09.11.2019
}

Rukwe DT*, Abdullahi YM, Faruk AU and Nwaeze U

National Agricultural Extension and Research Liaison Services, Ahmadu Bello University, Zaria, Nigeria

\begin{abstract}
The aim of this study was to evaluate the effects of Farmers-Herders conflict on the farming households of in southern Taraba State, Nigeria. The objective were to: describe the socioeconomic characteristics of crop farmers in southern Taraba State; ascertain the causes of conflict between farmers and herdsmen as perceived by crop farmers and ascertain the effects of the conflict on livelihood of farming households in southern Taraba State. Data were collected from 102 farming households using structured questionnaire, as respondents for the study. Multi-stage sampling was used for the study. Descriptive statistics was used to analyze the data collected. The results of the study shows that $61.8 \%$ of farmers were males, Majority $(81.4 \%)$ of the farmers fell within $21-50$ years with mean age of 41 years, majority (55.9\%) were married with average household size of 11 persons. Majority of the farmers are predominantly small-scale farmers with average farm size of 2.82 ha, about $88.2 \%$ of the rural farmers had formal education. The major crops grown were cereals crops (47.1\%), $73.5 \%$ of the respondents belonged to organizations with average annual income of farmers was N181, 050.52. The major perceived causes of conflicts by crop farmers in the study area was uncontrolled grazing and damage to crops by cattle (95.1\%). The most severe consequences of conflicts were decrease in output and income of farmers $(99.0 \%)$ and Loss of lives and injuries sustained (98.0\%). It was concluded that Farmers-herders conflicts are destructive and have far reaching consequences on livelihoods farming household as well as rural development in Taraba State and Nigeria at large if left unchecked quickly. It was recommended that intensive system of grazing, through ranching should be introduced so that cattle's are restricted to a particular place and chances of future clashes foreclosed.
\end{abstract}

Keywords: Conflict, farmers, herders, households.

\section{INTRODUCTION}

Farming and Pastoralism communities have over time developed interdependent relationships through reciprocity, others by exchange and support [1], and have been the primary source of livelihood for most farming households in developing countries including Nigeria, making them depend mostly on renewable resources. The produce of farming households and herdsmen remains the primary source of food for both the rural and urban population in developing countries such as Nigeria, Ghana, Cameroon, Tanzania and Kenya. For instance, IFAD [2] reported that smallholder farmers in Asia and sub-Saharan Africa produce $80 \%$ of the food they consume, which is thus the major source of food security. But in several West African countries like Nigeria, recurrent farmer-herder conflicts threaten peace, food security, economy and the livelihoods of Rural farmers, since such conflicts are on the rise and often violent in the sub-region.

There have been numerous cases of farmers-herders conflicts across various states in Nigeria. These conflicts have now become so intimidating on the country's national unity, such that the previous peaceful relationship between farmers and herders across various parts of Nigeria is degenerating to a carnage level, leading to loss of lives and properties [3]. Attempts by the federal government to curtail the continual farmers-herders appear to be ineffectual. However, before the present farmers-herders conflict assumed a dangerous dimension; the relationship between them had been a cordial and symbiotic one [4]. He further asserted that the sufficiency of land for both farmers and herdsmen, given the subsistence nature of farming and the few numbers of cows that the herdsmen breed then, made them to co-exist peacefully, void of unhealthy competition over scarce resources. This same cordiality had usually played out between farmers and herdsmen in Nigeria until recently [5].

Copyright @ 2019: This is an open-access article distributed under the terms of the Creative Commons Attribution license which permits unrestricted use, distribution, and reproduction in any medium for non commercial use (NonCommercial, or CC-BY-NC) provided the original author and source are credited. 
However, farmers-herders conflicts arose from increase competition over arable land use as a result of the increase in population of both the farmers and the herders. Other causes of the conflict include: expansion of farming on pastures, invasion of farmlands by cattle, assault on female farmers by herders, blockage of stock routes and water points; burning of rangelands, cattle theft; change in climatic condition leading to draught and dessert encroachment; improvement in technology that brought about irrigation, the need to cultivate and produce more of the cash crops newly introduced. Conflict between farmers and herdsmen is reinforced by the farmers' habit of extending the boundary of their farms to livestock route and the herdsmen's habit of allowing cattle to veer into the farmers' farm to eat their plants and drop their dung either on the farm or on the pedestal route [6].

Nigeria is under a severe internal and external security threat as the menace has political, economic and environmental dimensions. Each of these has critically affected the stability of the Agricultural production and can be traced to many factors in which the herdsmen appears to be major factor. Most worrisome in the present development is the pillaging, raping, killing and kidnapping by the so called herdsmen [7]. Stories are found in the national dailies on daily basis of how these shepherds strategically attack several communities and houses, with sophisticated assault guns-AK-47 [8]. Farmers can no longer farm peacefully because of Fulani herdsmen. These herdsmen and farmers clash have pitched Christians and Muslims against each other. Recent studies conducted by Okereke [9] and Kasarachi [7] have shown that, serious conflict erupt between herdsmen and farmers leading to loss of lives, valuable properties and destruction of vast expanse of arable agricultural farmlands thereby posing serious threat to food security, since farmers, for fear of attack could no longer go to farm and harvest their farm produce. The latest attacks by herdsmen is on the increase, with the most latest attacks in 2017-2018 happening in Taraba State, Benue State, Nassarawa State and few cases of attack in other states. As a result, in 2018 some states Governors have been quoted as preaching for Nigeria's disintegration. For instance, the Benue and Taraba state Governors, Samuel Ortom and Arc. Darius Dickson Ishaku implemented anti-open grazing law as a means of tackling famers-herders conflict in the states. Many people (especially herdsmen) sight the anti-open grazing law as a dangerous ploy, oppressive and negative which emerged as a populist agenda designed by visionless and desperate politicians to destroy the pastoralist culture and economic livelihood of the herdsmen, and that agricultural practices in Benue and Taraba States are not in line with international best practices as such singling out the pastoralist and insisting that they must ranch which is the global best practice is not fair [10].

In Taraba State, there have been instances of conflict between herders and farmers in Takum, Ussa, Wukari, Lau, Sardauna, Gassol, Ibbi, Bali, LGAs and other parts of the state over crop destruction by cattle, killing of a herder and stabbing of a farmer, following reprisal attacks on different occasions. Farmers-herders conflict is now said to be of co-extensiveness with religious, tribal and culture conflicts in Taraba State. This is because; most farmers tend to be of the same ethnic group and mostly Christians especially in the southern part of the state while most pastoralists are Fulani and mostly Muslims. In an event of a conflict between these groups, they are easily perceived as ethnic or religious conflicts because of their closeness in such lines. A good example of this was 2013-2015 Wukari crises that erupted from communal clashes between farmers and herders where many Christians as well as Muslims have been killed and many valuables were been destroyed. Another example was 2010 Jos crisis that snowballed from leadership tussle between the Hausa residents and the settlers in the area [3]. The aggression on the Hausa was easily transferred to the Fulani because it was perceived that they are of the same religion. This misrepresentation was partly responsible for the southern Kaduna crisis, where scores of Christians were gruesomely murdered and many churches burnt down.

Conflict in southern Taraba State threatens the livelihood resources of people particularly farming communities due to high dependent on natural resources for survival. Herder-farmer conflicts not only have a direct impact on the lives and livelihoods of those involved, they also disrupt and threaten the sustainability of agricultural and pastoral production in the area and invariably the sustainability of livelihoods of the farming households. The frequent occurrence of herdsmen and farmers conflict appears to have left adverse effects on livelihood of the farming households in the area. Farmers and herdsmen conflict no doubt have negative impact on social and economic development in Taraba State and Nigeria at large. The problem of this study is there to assess the effects of Farmers-Herders conflict on the livelihood of farming households in southern Taraba State, Nigeria. Thus, the study aimed to:

- Describe the socioeconomic characteristics of crop farmers in southern Taraba State;

- $\quad$ Ascertain the causes of conflict between farmers and herdsmen as perceived by crop farmers and

- Ascertain the effectsof the conflict on livelihoods of farming households in southern Taraba State.

\section{Methodology}

\section{The Study Area}

The study was conducted in Southern part of Taraba State, Nigeria. The southern part is made up of five Local Government areas (Takum, Wukari, Donga, Ussa, and Ibbi) and one special Development Area (Yangtu). It lies between latitudes $8^{\circ} 30^{\prime} 0^{\prime \prime}$ and $9^{\circ} 30^{\prime} 0^{\prime \prime} \mathrm{N}$ of the Equator and between longitudes $8^{\circ} 30^{\prime} 0^{\prime \prime}$ and $10^{\circ} 30^{\prime} 0^{\prime \prime} \mathrm{E}$ of the Greenwich Meridian. The area covers an area of $14,099 \mathrm{Km}^{2}$ land mass with a population of about 687,077 people as at 2006 (NPC2006). The National Population Commission had projected an annual growth rate of 3.5\% which brought the population figure to 969,189.96 people as at 2016 (Taraba State Government (TRSG), 2016). The area shares boundaries with Gassol, Bali, Kurmi, Gashaka and Karim-lamido Local Government areas in the North, Nasarawa State and Plateau State to the North-west, Benue State in the South-West and Republic of Cameroun in the South-East. It has a tropical wet and dry seasons, well drained alluvial soils and characterized by both savannah and rain forest 
vegetations. Its dry season lasts for a minimum of four months (December to March) while the wet season spans early March to late November in the south. The area has mean annual rainfall of $1800 \mathrm{~mm}$. Majority of the population consists of peasant farmers cultivating food and cash crops like sorghum, Yam, Maize, cassava, Sesame, rice e.t.c, at a small-scale level, fresh water fishing and forestry. Livestock keeping is a minor occupation of the population of the area dealing on goats, sheep, rabbits and fish farming. Other activities include trading and civil service. The people live mostly in organised settlements, towns and villages. The indigenous ethnic group found in the area is Jukun (that is Kuteb, Wapan, Wanu, Kpanzun, and Ichen) and others are Tiv, Chamba, and Hausa just to mention a few [11].

\section{Method of Data Collection}

Data for this study were collected from both primary and secondary source. The primary data were collected using structured questionnaire. Data collected include: (a) the farmers' socio-economic characteristics such as; gender, age, household size educational level, farm size, methods of land acquisition, membership of cooperatives, types of crop grownand amount of credit obtained. (b) Causes of conflict between farmers and herdsmen. (c) effects of conflict on livelihoods of farming households in southern Taraba State.

\section{Sampling Technique and sampling size}

Three stage sampling was used for this study. In the first stage, three Local Government Areas from the zone (Takum, Ussa and Wukari), were purposively selected due to prevalence of Farmers-Herders conflicts in the zone. In the second stage, three villages from each of the three selected Local Governments Areas were randomly selected. In the third stages, respondents were selected from each of the four villages in proportion to their population. Finally, $10 \%$ of the respondents were randomly selected from each of the four villages selected form the sample size for the study. A well-structured questionnaire was administered to 121 respondents, out of which 102 questionnaires were properly filled and returned back. Analysis for this study was done based on the number of questionnaires that were retrieved.

\section{Analytical Techniques}

Descriptive statistic was used to analyze the socio-economic characteristics of the farmers, ascertain the perceived causes of conflict between farmers and herdsmen and ascertain the effects of conflict on livelihoods of farming households in southern Taraba State.

\section{RESULTS AND DISCUSSION}

\section{Socio-economic characteristics of respondents}

Results on socioeconomic characteristics of farming households in the study area are shown in Table 1. Table 1 indicates that $61.8 \%$ of crop farmers were males, meaning that the dominance of males in farming probably because men are more energetic and capable of involving in tedious production activities associated with farming than women. This result collaborates with that of Dimelu et al. [12] who found that $85.2 \%$ of crop farmers were males. Majority (81.4\%) of the farmers fell within $21-50$ years with mean age of 41 years indicating that the farmers are still in their active and productive years. Consequently, they may respond violently to conflict or aggression from herdsmen due to youthful exuberance. Majority (55.9\%) were married with average household size of 11 persons. Rural farmers have a large household size which may have resulted from the need for family labour with the consequence of more dependant family members. This is in line with the finding of Olobatoke and Omowumi [13] who revealed that majority of the farmers are married implies that they may be able to utilize family labour to reduce input costs and increase productivity. Majority of the farmers are mostly small-scale farmers with average farm size of 2.82 ha. This may be because they acquire land for farming mainly by inheritance and may indicate the practice of individual system of land ownership. It is in confirmation with the study of Dimelu et al. [12] who reported that the respondents are subsistence farmers with average farm size of 2.9 ha. With respect to education, about $88.2 \%$ of the rural farmers had formal education. Though, the farmers are literate but the educational level attained is relatively low. Only $24.5 \%$ had higher qualification. This could negatively affect the farmers' perception of conflict situation and subsequently their behavior and altitude to conflict. This might be one of the reasons why farmer-herders' conflict has remained unabated and a regular phenomenon in the state [14]. The major crops grown were cereals crops (47.1\%), root crops (40.2\%), vegetable and legume (31.4\%) and tree crops (11.8\%). According to Olabode and Ajibade [15] some of these crops (yam, maize, Rice and guinea corn) are of nutritional value and attractive to cattle. Consequently, the farms could be a source of conflict as herds get attracted to the crops during grazing. Majority (73.5\%) of the respondents belonged to organizations. This is not only a real tool for enhancing production through economy of scale, but more importantly, an instrument for conflict resolution and sustainable peace when effectively yoked. According to Ekong [16] membership of social organization in the rural areas is of immense value if such organizations could help members accomplish tasks an individual cannot achieve alone. The average annual income of farmers was $\mathrm{N} 181,050.52$. This is below one dollar per naira, showing the level of poverty in the farming communities. Thus, attacks on the farms could attract serious dispute with opponents, being the major means of livelihood. The farmer-herders' conflict are often a consequence of struggle for survival [12]. 
Table-1: Socio-economic characteristic of the crop farmers

\begin{tabular}{|c|c|c|c|}
\hline Variables & Frequency & Percentage & Mean \\
\hline $\begin{array}{l}\text { Gender } \\
\text { Male } \\
\text { Female }\end{array}$ & $\begin{array}{l}63 \\
39\end{array}$ & $\begin{array}{l}61.8 \\
38.2\end{array}$ & \\
\hline $\begin{array}{l}\text { Age (years) } \\
11-20 \\
21-30 \\
31-40 \\
41-50 \\
51-60\end{array}$ & $\begin{array}{l}5 \\
17 \\
23 \\
43 \\
14\end{array}$ & $\begin{array}{l}4.9 \\
16.7 \\
22.5 \\
42.2 \\
13.7\end{array}$ & 42 \\
\hline $\begin{array}{l}\text { Marital status } \\
\text { Single } \\
\text { Married } \\
\text { Widows/widowers }\end{array}$ & $\begin{array}{l}24 \\
57 \\
21\end{array}$ & $\begin{array}{l}23.5 \\
55.9 \\
20.6\end{array}$ & \\
\hline $\begin{array}{l}\text { Household size } \\
1-5 \\
6-10 \\
11-15 \\
16-20\end{array}$ & $\begin{array}{l}12 \\
29 \\
51 \\
10\end{array}$ & $\begin{array}{c}11.8 \\
28.4 \\
50.0 \\
9.8\end{array}$ & 11 \\
\hline $\begin{array}{l}\text { Farm size (ha) } \\
<1 \\
1-2 \\
3-4 \\
5 \text { and above }\end{array}$ & $\begin{array}{l}14 \\
48 \\
31 \\
9\end{array}$ & $\begin{array}{l}13.7 \\
47.1 \\
30.4 \\
8.8\end{array}$ & 2.82 \\
\hline $\begin{array}{l}\text { Educational level } \\
\text { No formal education } \\
\text { Primary education } \\
\text { Secondary education } \\
\text { Tertiary education }\end{array}$ & $\begin{array}{l}12 \\
17 \\
48 \\
25\end{array}$ & $\begin{array}{l}11.8 \\
16.7 \\
47.0 \\
24.5\end{array}$ & \\
\hline $\begin{array}{l}\text { Types of crop grown } \\
\text { Cereal crop: Maize, Rice, millet, sorghum etc } \\
\text { Root crops: Yam, Cassava, potato, etc } \\
\text { Tree crops: cashew, Mango, Palm tree, Orange, etc. } \\
\text { Legume and Vegetable }\end{array}$ & $\begin{array}{l}48 \\
41 \\
12 \\
32 \\
\end{array}$ & $\begin{array}{l}47.1 \\
40.2 \\
11.8 \\
31.4 \\
\end{array}$ & \\
\hline $\begin{array}{l}\text { Membership of organization } \\
\text { Agricultural organization } \\
\text { Religious organization } \\
\text { Social clubs } \\
\text { Non-Membership of organization }\end{array}$ & $\begin{array}{l}22 \\
34 \\
19 \\
27\end{array}$ & $\begin{array}{l}21.6 \\
33.3 \\
18.6 \\
26.5\end{array}$ & \\
\hline $\begin{array}{l}\text { Income } \\
<100,000 \\
100,001-200,000 \\
200,001-300,000 \\
300,001-400,000 \\
400,001-500,000 \\
>500,000\end{array}$ & $\begin{array}{l}5 \\
31 \\
32 \\
14 \\
9 \\
11\end{array}$ & $\begin{array}{l}4.9 \\
30.4 \\
31.4 \\
13.7 \\
8.8 \\
10.8\end{array}$ & $181,050.52$ \\
\hline Total & 102 & 100 & \\
\hline
\end{tabular}

\section{Perceived causes of conflict between herdsmen and farmers by Crop farmers}

The perceived causes of conflicts by crop farmers in the study area were ranked according to their magnitude as stated by the farmers. Table 2 shows uncontrolled grazing and damage to crops by cattle( $95.1 \%)$, burning of range land $(90.2 \%)$, herders claiming the land as common property( $84.3 \%)$, Contamination of stream by cattle $(79.4 \%)$ and Non-compliance with laid down rules $(74.5 \%)$ were the major causes of conflict in the area. This implies that herders always were not able to control their cattle during grazing as the larger the herd size, the more difficult it is to control the herd. This commonly led to consumption or destruction of crops. The traditional practice of burning range land is common among herders and is carried out to stimulate early emergent of fresh pastures as the dry vegetation get burnt. Often in the process of burning, fire spreads into adjourning farms destroying farms, stored food stuff in the bans and farm implements [12]. Over- stay in a location by herdsmen could result to destruction of farm land, pilfering from farms and burning of range land. As herders stay long in an area, the hoof of animal irreversibly hardens the soil upon which they pass and makes cultivation extremely difficult. In most communities in the study area, herders are given temporal settlement right mostly during dry season which they often over-stay and subsequently demand equal right of tenure and exploitation. This largely accounts for greater conflict situations in almost all part of Taraba state Nigeria at large. This is in congruence with Ofem and Inyang [14], who reported that burning of range land, pollution of water source, disrespect for traditional leaders, and destruction of farmland were the major causes of conflict between herders and farmers. Similarly, Adebayo and Olaniyi [17], further reported grazing on 
harvested crops, theft of farmers' produce by herders and pulverization of soil, among others as causes of conflict between crop farmers and herders.

Table-2: Causes of conflict as perceived by crop farmers

\begin{tabular}{|l|l|l|l|}
\hline Causes & Frequency & Percentage & Rank order \\
\hline Uncontrolled grazing and damage to crops by cattle & 97 & 95.1 & 1 \\
Burning of rangeland & 92 & 90.2 & 2 \\
Herders claiming the land as common property & 86 & 84.3 & 3 \\
Contamination of stream by cattle & 81 & 79.4 & 4 \\
Non-compliance with laid down rules & 76 & 74.5 & 5 \\
Pilferage from the farmers farms & 74 & 72.5 & 6 \\
Little respect for traditional gazing custom & 73 & 71.6 & 7 \\
Herders' over stay in a location & 62 & 60.8 & 8 \\
Cattle herders not obeying the elders & 54 & 52.9 & 9 \\
Population growth & 53 & 51.1 & 10 \\
Destruction of farm land & 52 & 50.1 & 11 \\
Sexual harassment of women by nomads & 45 & 44.1 & 12 \\
Language barrier & 43 & 42.2 & 13 \\
Cultural differences & 34 & 33.3 & 14 \\
Disregard of traditional authority & 23 & 22.5 & 15 \\
\hline
\end{tabular}

Source: Field survey, 2018

\section{Consequences of conflict on crop farmers}

Most respondents suffered various effects as a result of conflict. The consequences of famers-herders conflict as perceived by crop famers were ranked in order of their severity in table 3 . The most sever ones were reduction in output and income of farmers $(99.0 \%)$, Loss of lives and injuries sustained $(98.0 \%)$, absence of agricultural labour force $(97.1 \%)$, Loss of crop on the field/store (95.1), Unsaved environment for farming (93.1\%), displacement of farmers (92.2\%) and reduction in household resources (91.2\%). These variables have positive relationship, which means that conflict increases the above mentioned conditions of life and is as well exacerbated by these conditions. Similar studies also reported loss of a whole farm of standing crops, loss of human lives, and quality of relationship and material resources [18, 19]. Reduction in output and income of crop farmers occur as a result of none expansion of farm land, indiscriminate bush burning and destruction of crops by cattle which lead to either partial or total loss of crops by the farmers. Similarly, agricultural labour usually supplied by rural youths/households is seriously affected due to loss of life and displacement. Most youths migrate to more peaceful locations, thereby creating labour scarcity in the conflict-stricken zones. This negatively impacts on human capital formation as well as agricultural productivity, and subsequently farm decision and livelihood activities. The effect on crop yield therefore has negative impact on the affected farmer's income with its summary impact on the overall agricultural income. This tends to negatively affect farmer's savings, credit repayment ability, and inability to effectively feed their families and could not pay children's school fees as well the food security and economic welfare of urban dwellers that depend on these farmers for food supply, thus, farming and rural development is discouraged. This infers that the farmers-herders conflicts have a negative impact on the livelihood of crop farmers. In addition, farmers who could not repay their loans may not be able to access further loan facilities and inability to pay school fees could invariably draw back educational status which is supposed to actually assist in reducing poverty in the area. This is in line with the study of Opoku [19] who reported farmer's inability to pay children's school fees, the deficiency he attributed to reduction in the income of the farming families. Another effect is displacement of farmers. Internal displacement of farmers in communities occurs as a result of the conflict, especially women, who decided to stop going to the distant farm for fear of attack by nomads. The displaced farmers have therefore become a liability to other farmers who has become a source of providence for them and their families which has created a vicious cycle of poverty in the affected. Also the killing of male has made some female farmers to widows during the conflicts as well as increase Teenage pregnancy.

Table-3: Perceived Consequences of conflict on crop farmers

\begin{tabular}{|l|l|l|l|}
\hline Variables & Frequency & Percentage & Rank order \\
\hline Decrease in output and income & 101 & 90.0 & 1 \\
Loss of lives and injuries sustained & 100 & 98.0 & 2 \\
Absence of agricultural labour force & 99 & 97.1 & 3 \\
Loss of crop on the field/store & 97 & 95.1 & 4 \\
Unsaved environment for farming & 95 & 93.1 & 5 \\
Displacement of farmers & 94 & 92.2 & 6 \\
Reduction in household resources & 93 & 91.2 & 7 \\
Increased number of widows, widowers and orphan & 90 & 88.2 & 8 \\
Declining quality of children's education & 88 & 86.3 & 9 \\
Teenage pregnancy & 84 & 82.4 & 10 \\
Misbehaving and uncontrollable conduct of youth & 78 & 76.5 & 11 \\
Proliferation of small arms & 75 & 73.5 & 12 \\
Marital dissatisfaction & 66 & 64.7 & 13 \\
\hline
\end{tabular}

Source: Field survey, 2018 


\section{CONCLUSION}

Farmers-herders conflicts are destructive and have far reaching consequences on farming household'slivelihood assets as well as rural development in Taraba State and Nigeria at large if left unchecked hurriedly. The results show that conflicts are associated with livelihood pressure and competition between crop farmers and herdsmen. Specifically, the dominant composite causes revealed in the study we reuncontrolled grazing and damage to crops by cattle, burning of rangeland, Herders claiming the land as common property, contamination of stream by cattle and non-compliance with laid down rules. Consequently, this impacts the entire livelihood assets of crop farmers ranging from physical, natural, human, financial, and social to political assets. The livelihood structure, food security and wellbeing of farming households are threatened and compromised which contribute to poverty, food insecurity and poor health of farming communities, and further escalation of conflicts.

\section{RECOMMENDATIONS}

Drifting system of herding is old and out-of-date given the present state of development, population growth and advancement in technology. It is therefore, suggested that ranching should be introduced so that cattle will be restricted to a particular place and close out chances of futures clashes and Government should be firm and fair in its resolution and execution of decisions.

\section{REFERENCES}

1. Moritz, M. (2010). Understanding herder-farmer conflicts in West Africa: Outline of a processual approach. Human Organization, 138-148.

2. IFAD, U. (2013). Smallholders, food security and the environment. Rome: International Fund for Agricultural Development.

3. Aliyu, M. K., Ikedinma, H. A., \& Akinwande, A. E. (2008). Assessment of the Effect of Farmers-Herdsmen Conflicts on National Integration in Nigeria.

4. Nzeh, E. M. E. K. A. (2015). The effects of migration by nomadic farmers in the livelihoods of rural crop farmers in Enugu state, Nigeria. Global Journal of Science Frontier Research: D Agriculture and Veterinary, 21-28.

5. Goke, S. (2018). The Genesis of Farmers-Herdsmen Clashes in Nigeria. Journal of Social Sciences, 4(2), 34-48.

6. Moritz, M. (2003). The demise of the nomadic contract: arrangements and rangelands under pressure in the far north of Cameroon. Nomadic Peoples, 6(1):127-146.

7. Kasarachi, N. P. (2016). Institutionalizing peace education for sustainable development in public secondary schools in Delta State. Niger Delta Journal of Education, 8(1); 194-196.

8. Ajibefun, M. B. (2018). Social and Economic Effects of the Menace of Fulani Herdsmen Crises in Nigeria. Journal of Educational and Social Research, 8 (2); pp133-139.

9. Okereke, D. (2012). The remote immediate cause of crimes, insecurity, terrorism and instability in Nigeria and solution. Retrieved from http://www.nairand.com/1027585/remote-immediatecauses- crimes on January 19th, 2018.

10. Williams, A. A. (2018). Herdsmen and Farmers Conflict in Nigeria: Dimensionof Insecurity. Journal of Public Administration and Social Welfare Research, 3(1); 35-62

11. Elizabeth, A.I. (1997). A history of African societies to 1870. Cambridge University press.

12. Dimelu, M. U., Salifu, E. D., Chah, J. M., Enwelu, I. A., \& Igbokwe, E. M. (2017). Livelihood issues in herdsmen-farmers' conflict among farming communities in Kogi State, Nigeria. African Journal of Agricultural Research,12(24):2105-2115. http://www.academicjournals.org/AJAR.

13. Olobatoke, R., \& Omowumi, A. (2017). Effect of Fulani herders' intrusion on the economic livelihood of crop farmers in Yagba East Local Government Area of Kogi State, Nigeria. International Journal of Agricultural Policy and Research, 5(3): 80-85. https://www.journalissues.org/lJAPR

14. Ofem, O. O., \& Inyang, B. (2014). Livelihood and Conflict Dimension among Crop Farmers and Fulani Herdsmen in Yakurr Region of Cross River State. Mediterranean Journal of Social Sciences, 5(8); 512-519.

15. Olabode, A.D., Ajibade, L.T. (2010). Environment induced conflict and sustainable development: A case of Fulani-farmers' conflict in Oke-Ero L.G.A. Kwara State Nigeria. J. Sustain. Dev. Afr. 12: 259-262.

16. Ekong, E.E. (2010). Introduction to rural Sociology. Uyo, Nigeria, Dove Educational Publishers, 70-85.

17. Adebayo, O. O., \& Olaniyi, O. A. (2008). Factors associated with pastoral and crop farmers conflict in derived Savannah Zone of Oyo State, Nigeria. Journal of Human Ecology, 23(1), 71-74.

18. Fiki, C., Lee, B. (2004). Conflict generation, conflict management and self-organizing capabilities in drought-prone rural communities in Northeastern Nigeria: A case study. J. Soc. Dev. Afr, 19:25-48.

19. Opoku, P. (2015). Economic impacts of land-use conflicts on livelihoods. A case study of pastoralists-farmer conflicts in the Agogo Traditional Area of Ghana. JENRM, 2(1), 1-7 